\title{
THE UNCOMPENSATED ACCIDENT AND ITS CONSEQUENCES
}

\author{
Emma Corstret*
}

A friend of mine, young, handsome and a wit, the wife of a lawyer and mother of two youngsters of three and four, was riding on the Post Road on a Sunday afternoon. Another automobile careened towards her car, bumped it, skidded off and disappeared around a corner. It required only a minute for all this to happen; but within that minute Theresa had been thrown out of the car, flung against a stone and was dead. To us, shocked and incredulous friends who read about it in the paper, it was not one of the 33,000 killed that year by motor cars. It was Theresa, whose outrageously bland fibs were always waiting to catch us unawares, who had built up around her this charming home which now, senselessly, was shattered.

About the same time in Connecticut, Steve Carlson, a laborer, was injured in an accident, his hip smashed. While he was in the hospital and for sometime afterwards, his wife and children managed. They borrowed from relatives, used up small savings, exhausted their credit with the grocer. The rent fell behind. Finally, a year later, the family gave up and was taken in by his parents until such time as "maybe his sickness gets better." There was no compensation. There was no newspaper report of this unimportant series of events; it is recorded only in statistics which state that about a million people were injured that year by automobiles.

A little later in the year, Pasquale Miniotti was killed while crossing a street. A brief notice in the local paper stated that the driver had been found by the coroner to have been drinking and was arrested for homicide but later released. The widow got $\$ 500$ life insurance, more than half of which she foolishly spent on the funeral. Seven months later she was living on occasional gifts from her former husband's employer and on gifts of food from neighbors. The landlady had not yet had the heart to put her out. There had been no compensation.

These three people-or, rather, those three families-represent part of a price paid by some individuals for the physical progress of society. And however much we may dislike this particular type of tribute paid to the automobile, we can no more scrap the motor car than we can the Diesel engine, the linotype or the stretch-out system. Clever engineers and inventors produce the new tool and society, adopting

- Assistant Professor of Social Sciences, Yale University, Institute of Human Relations, 1929-36. In charge of case studies of automobile accidents in Connecticut for the Committee to Study Compensation for Automobile Accidents. Contributor to legal and social science periodicals. 
its advantages, learns only gradually that it carries a human cost which must be reflected in a modification of the social structure.

The concern of this article is not with reduction of accidents, itself an important . problem. It is not with such social consequences as followed upon Theresa's death, the husband's grief, the suddenly unprotected world of the children. It is with Pasquale's widow and the family of Steve-with the blunt consequences of lack of money. We are dealing not with rights, duties, privileges and immunities but with certain social facts. Assuming that accidents can never be eliminated, at what human cost does the present compensation structure function? But first we must know how it functions. ${ }^{1}$

If no liability compensation is received by the injured person, there are other possible sources through which he may recoup his loss or part of it, such as insurance policies, employer's continuing wage, free care or gifts of friends. Our Connecticut studies for the Committee to Study Compensation for Automobile Accidents showed that in $14 \%$ of the injuries some compensation of this type was received. ${ }^{2}$ Occasionally it was really substantial. There was, for example, a severely injured linesman with four dependents, including a new baby. The operator of the car spent 30 days in jail, but the car was in his wife's name and no compensation was received. For over a year the fellow employees of the injured man took over his shift, dividing the time between them so that he might be paid. But this is exceptional. Most compensation of this type is small. Gifts are generally limited to neighborly bowls of broth or the custodianship of children while sickness is in the house. An employer does not normally feel it necessary to carry along a worker for whom he is not liable. Accident insurance is the privilege of those with some surplus income. And though the poorest family hangs on to its Io cents a week insurance payment, the policy this represents is not generally large. When compensation was received, the most usual amount (excluding fatal cases) was from $\$ 10$ to $\$ 24$. In fatal cases it was about $\$ 500$ to $\$ \mathbf{r}, 000$.

It appears, then, that except in fatal cases, little is to be expected from any source other than liability compensation. And this depends not only upon proof of the

\footnotetext{
1 The writer has not attempted here a "scientific" description. Although she believes that figures have been accurately presented, lack of space prevents the careful definition and qualification necessary for a cautious treatment of them. For a presentation of most of the figures and the wherewithal for evaluating them, those interested are urged to examine the Report by the Committee to Study Compensation for Automobile Accidents to the Columbia University Council for Research in the Social Sciences (1932), especially pp. 218-35 and the appendix. The Committee's total figures cover investigations in ten localities of the United States. However, as the two Connecticut studies were the most detailed, many figures are, of necessity, taken only from these studies. Connecticut is a state having a financial responsibility law but no compulsory insurance requirements. At the time of the investigation $55 \%$ of all cars within the state were insured. This was not typical of the country, since only one state, Massachusetts, had a higher percentage of insured cars. The bias in Connecticut figures, it will be noted, is in terms of greater-thanaverage insurance and consequently more frequent compensation.

In Connecticut $92 \%$ of the temporary, $83 \%$ of the permancnt, and $32 \%$ of the fatal injuries received no compensation from any source other than the liable party.
} 
"liable party's" negligence and of the absolute freedom from negligence of the injured person but on financial responsibility and bargaining power. The test of the first two is what the courts do about them and probably less than I per cent of the cases ever come to trial. The test of financial responsibility is usually insurance. The figures of the Committee to Study Compensation for Automobile Accidents show how small is the chance of getting any compensation if the driver-owner is not insured. If the liable party is financially responsible, the bargaining process and the antagonists' respective opinions on legal responsibility become intermixed. If the financially responsible person or his insurance company regards himself as probably liable a figure may be ultimately agreed upon. In a sense, the ultimate price of an auto accident, when there is one, is fixed by the higgling of the market. But unlike the picture of the neo-classic economist, there is no row of buyers opposed to a row of sellers. Neither buyer nor seller has competition, and the outcome depends only on their relative strengths. In small claims the injured has often an advantage. His claim may not even be good in law, but he can harry the other man and cause him expense of a trial greater than the amount which would lead to settlement.

But, in general, the injured is at a disadvantage in bargaining. A part, in fatal cases, is psychological. To haggle over payment for a death may be, to those who can afford the luxury of sensibility, like taking 30 pieces of silver for a beloved person. And occasionally people who cannot afford this luxury also feel the same way in the midst of grief. But the great disadvantage to the injured is that while the buyer of a waiver of future claims is not anxious to buy at all unless the horizon is really threatening, the seller must sell to this buyer or none at all. His costs have been forced from him, he must recoup what he can. And, if the outlay has been serious, the injured often needs money and at once. In Connecticut $25 \%$ of the injured had a total family income of $\$ 1,500$ a year and $59 \%$ less than $\$ 2,500$. $31 \%$ were either sole family supporters or one of two. Such a situation leaves little leeway for unforeseen emergencies. The family doctor may wait, the landlord be generous, the grocer, up to his limited means, give credit. But a nurse is not a capitalist and needs her wage at once, a specialist is not the family doctor, the need for coal and light, medicine, special sick foods and some unavoidable necessities of family living goes on. The result is that the families most in need of compensation can often least afford to hold out for an ádequate price, i.e., a price commensurate with expenditure and as great as those who can afford to wait might obtain.

${ }^{8}$ This term will be used herein to designate the person whom the injured person alleges to be responsible, although actually he may never be held liable or admit his negligence.

'Committee's Report, supra note I, at p. 76 et seq. Injuries Not Compensated by Liable Party (Closed Cases OnLy)

\begin{tabular}{|c|c|c|}
\hline $\begin{array}{l}\text { Insured .... } \\
\text { Not insured }\end{array}$ & $\begin{array}{l}\text { Temporary } \\
\text {.. } 14 \% \\
. \quad 73 \%\end{array}$ & $\begin{array}{c}\text { Permanent } \\
4 \% \\
79 \%\end{array}$ \\
\hline
\end{tabular}

The infrequency of compensation from liable parties not insured is probably related to the fact that people with assets regard insurance as property protection whereas people without it often say blithely, "What if something does happen. No one can get anything out of me. I haven't got anything." 
In the results of bargaining, then, there is often neither rhyme nor reason. Small injuries receive more than large ones. In fatal cases, where the troublesome task of determining the extent of injuries is grimly obviated, $\$ 5^{\circ}$ is received for one young child, $\$ 1,800$ for another. For the death of one married man of about 30 , with several dependents, $\$ 200$ is received; for another in approximately the same position, $\$ 5,000$.

It has been said that, if compensation is received at all, the ability to wait is an important factor in bargaining for the amount. It would seem that either party has power to terminate the deal-the injured by accepting $\$$ I for a hundred dollar injury, the liable party by paying \$1oo for a dollar injury. If the injury is temporary, either party may be the one who is holding off, the liable party because he is, naturally, in no hurry to part with his money or because he thinks too much is asked, ${ }^{5}$ the injured because expense is so small that he can afford to wait or because he feels he cannot afford to take the price tendered. In the longer temporary injuries and in permanent injuries, it is often the liable party who is more apt to want the business closed. Here the injured is caught between two fires, and is peculiarly vulnerable. He does not wish to settle before knowing the extent of his losses. On the other hand he receives nothing until the settlement; meanwhile his need may be great and the present value of an uncertain future amount will be heavily discounted. It is in these cases that the swift reception of compensation may be of great importance. In fatal cases, even involving a sole earner, delay may or may not be important. If life insurance tides over the immediate crisis, it is the long vista of the future which counts.

Whatever the reasons, in Connecticut, compensation for temporary injuries, when received at all, was usually received fairly soon, while for permanent and fatal injuries settlements were slower. ${ }^{6}$

This bargaining process, it must be remembered, is seldom direct. It takes place through the mediation of two lawyers or a lawyer and an insurance adjuster. The injured's representative is most apt to take the case on a contingency basis, charging 25 to $50 \%$ and sometimes more. The lawyer's charge is usually subtracted before

"The writer does not mean to imply that all liable parties are scamps and all injured persons angels. The whole character of the bargaining smacks of the horsetrade. The defendant claims he was not negligent and, if he was, so was the plaintiff. The plaintiff claims he was utterly free from negligence and the defendant plainly careless. Actually, in most cases and aside from a firm conviction that the other fellow was wrong, neither party has any clear idea of what happened until time and the repetition of his wrong has fixed a firm memory in his mind. Moreover, the defendant claims the plaintiff was not really hurt or at least not badly, and the plaintiff exaggerates his injuries. As a result of this accepted style of bargaining either party, if he wishes to be decent, is at a disadvantage.

The judgments of extent of injuries employed here were primarily in terms of expenses and wage losses. In Connecticut plaintiff's temptation to exaggerate was corrected so far as possible by a system of checks with hospitals, doctors, employers, etc. It was found that, while extent of injury often appeared exaggerated, actual expenses were not, as a rule.

'Committen's RePORT, supra note I, at 'Pp. 93-94. The Committee to Study Compensation for Automobile Accidents reports that in cases where there was insurance, one-half of the permanent and fatal injuries were unsettled after 6 months and most of these after one year. Further, that their court record studies show that in cases which go to trial the total delay will be one to three years. 
the injured receives his check so that between the price paid by the liable party and the price received by the injured there exists a conspicuous difference.

A study of closed cases only, that is, cases exclusive of those where the matter was still pending or some hope of compensation still lingered, showed that more than half of the fatal and permanent injuries either had received nothing and expected to receive nothing or had received less than the actual expense of the accident. $^{7}$ This proportion was probably lower than the average since the figures were based on a series of studies which included two studies in Massachusetts, where insurance is compulsory.

But our concern is not so much with who gives compensation as with the extent of compensation received. If we lump all forms of compensation, whether from insurance, liable party, employer, etc., we have the following:

Balance of Compensation with Accident Expenses 8

RECEIVED

\begin{tabular}{|c|c|c|c|}
\hline Nothing & $\begin{array}{l}\text { All injuries } \\
\cdot \quad 41.6^{*}\end{array}$ & $\begin{array}{c}\text { Temporary } \\
43.2\end{array}$ & $\begin{array}{c}\text { Permanent } \\
48.3\end{array}$ \\
\hline Less than medical expense. & 6.7 & 5.5 & II.O \\
\hline Medical expense equivalent .... & 6.6 & 7.5 & $x .7$ \\
\hline ore than medical expense, less than total. & $1 x .2$ & rx.9 & rr.o \\
\hline Total expense or more...$\ldots \ldots \ldots \ldots \ldots$ & 33.9 & 32.6 & 28.0 \\
\hline
\end{tabular}

- $14 \%$ of these might in the future receive something. They were not closed.

In short, $67 \%$ of the temporary injuries and $72 \%$ of the permanent injuries had received less than the actual expenses of the accident. Of all cases, temporary, permanent and fatal injuries, $66 \%$ received less than the equivalent of actual expenses.

Fatal cases were not presented separately here. It would be ridiculous to present the cost of a fatal accident merely in terms of the funeral expense and the possible medical expense if the person killed were an earner. Yet potential wage loss is exceedingly difficult to estimate. ${ }^{9}$ If we do balance the immediate expenses of a

'According to a synthesis of the Committee's total figures for all closed cases, $47 \%$ of the temporary injuries, $56 \%$ of the permanent injuries, and $55 \%$ of those which were fatal received less than the expense of the accident. These figures include both insured and uninsured cars for the ten studies of the Committee. The states in which the studies were made varied between Massachusetts with almost $100 \%$ insured cars and Indiana with $15 \%$ insured cars.

The difference between insured and uninsured cars in coverage of losses by the liable party is brought out by the following figures from the Committee's Report (at p. 76 et seg.)

Coverage of Losses by Liabie Party (Closed Cases Only)

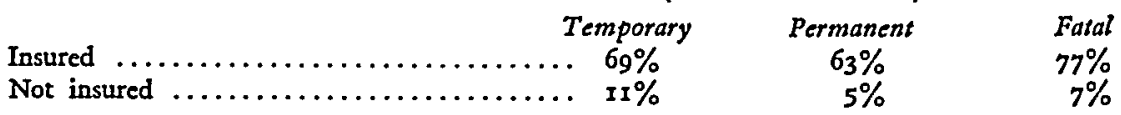

The heavy negotiation costs are subtracted from amounts calculated as received by injured. Thus, if the liable party paid $\$ 300$ and the lawyer kept $\$ 100$ for his services, amount received by injured is stated as $\$ 200$. If however, lawyer kept $\$ 100$ for himself, paid $\$ 100$ to hospital or doctor and turned over $\$ 100$ to injured, the amount received is still recorded as $\$ 200$, since only legal expense is excluded.

-See Dublin's The Money Value of a Man (1930) for a fascinating compilation of actuarial figures on losses. For example, the present worth of net future carnings of a man of 30 carning $\$ 1800$ a year is stated as $\$ 19,300$. The permanent partial disability of a man of 43 , with a salary of $\$ 2,500$, losing the use of an arm at the shoulder is $58 \%$ of total disability. His residual earning capacity is then stated as $42 \%$ of $\$ 2,500$, i.c. $\$ 1,050$ per annum and his residual economic value as $\$ 8,450$ instead of $\$ 23,450$. 
fatal accident with all compensation received, including life insurance, 54\% of the cases received an amount equal to the expense.

\section{II}

The situation just described is the outcome of our present social and legal machinery for providing compensation for automobile accidents. It has certain conspicuous features. Private means of compensation are unusual, except for whatever life insurance payment follows a fatal injury. The course of liability compensation follows a peculiar pattern. Even if legal liability is established there must be financial responsibility before compensation is obtainable. This, in practice, means that there is seldom compensation unless there is insurance. The amount of the compensation depends upon a process of bargaining which is expensive to both parties. Small injuries are often overcompensated and serious and expensive injuries undercompensated, after a long delay. Great differences exist in payments for the same disability and these differences are not in relation to need but, rather, in inverse ratio to it. Two-thirds of the injured must pay all or part of the accident expense themselves.

If we lay aside questions of justice, we have still to consider the effect upon human beings of this rather primitive method of dealing with the ruthlessness of a modern instrument. It may be unjust and yet present no serious social consequences. No situation, however undesirable, is I00\% lurid in its effects. Slavery produced only a small number of Uncle Toms. The industrial revolution did not really leave a nation in a state of malnutrition. Nor do all workers die of silicosis. All automobile accidents do not result in serious situations which could be alleviated by prompt and adequate compensation. The fatal accident of my friend Theresa could in no way have been softened in its results by the most lavish payment and many accidents, on the other hand, are so slight that only inconvenience attaches to them. But there remain the cases of Steve Carlson and Pasquale Miniotti. How many of these are there? Enough, it seems, to indicate serious maladjustment in the present social machinery. ${ }^{10}$ In Connecticut we found that $33 \%$ of the fatal injuries, $24 \%$ of the permanent, and $9 \%$ of the temporary injuries resulted in what was arbitrarily termed hardship which might have been removed or alleviated by adequate compensation promptly received. ${ }^{11}$ This is a situation comparable, possibly, to industrial accidents before the days of any industrial compensation, and it involves a group which is numerically increasing in importance.

There are some individuals who stand alone in the world. They are the mavericks and strays and the traditional orphan. When a crisis occurs in such a life, the

\footnotetext{
${ }^{10}$ The author, several years ago, when she made the field studies, would have regarded such a statement of sheer opinion with horror. The problem was to find out what happened and not to label it. But having done this, she now claims the right of a human being to have an opinion on what was found.

11 Total, for all cases, was $15 \%$. For a description of the measure used in an attempt at an objective judgment of what might be classed as "hardship," see CoMmITteE's REport, supra note x, at pp. 232233. The cases presented in the pages following are selected to illustrate points; they are not chosen by any sampling method.
} 
individual must meet it alone or society must help him. An accident to such a person may be a greater burden because he has no one to turn to, as it may be less serious because he has no responsibilities. There was, for example, the young lad who lost his arm as a result of an accident. He also lost his job and, receiving no compensation, had no means for rehabilitation training. He fell behind with his rent, his insurance policy lapsed, friends made up a purse for him and what became of him later is unknown.

Most people, however, are members of a family group. If the injured is not an earner or a sole earner, this group absorbs the shock and carries him along with them. If his place in the family is important, the crisis may be doubled by their dependence.

Those accidents, which resulted in what we term hardship for the injured or his family, did not, of course, include all accidents having disagreeable consequences. Disfigurement occurs and is not pleasant. A serious illness involves the strain of care and worry. The disappearance of a life's savings is a bitter thing. Pain accompanies injuries, grief remains after death, and sometimes a home is broken up. But - such cases are not of distress which compensation could prevent unless lack of money was the determining factor leading to positive changes. In some cases subsequent unemployment was carried by the family without derangement of its normal security. In others, where the cost of the accident was more than the family could shoulder, compensation took care of it or the family was able to slough off costs by the simple expedient of letting doctor and hospital foot the bill.

We are concerned with the other cases, where a social derangement did occur which might have been mitigated by adequate and prompt reception of compensation. The lack of medical care is one accompaniment of insufficient funds. There was a forewoman in a laundry in New Haven, who supported two children and an invalid husband. A driver skidded into her; he was held for reckless driving and the case nolled because the weather had been bad. Having no money in the house she had to go back to work with her head still heavily bandaged, after a week in bed. The driver, eventually, paid half her doctor's bill. And there was a child of four, who was standing by a telephone pole when a truck, backing round, knocked him down and ran over one foot. The father was a dish-washer with six dependents. The child was laid up four weeks with three visits of a doctor. No specialist could be called, and the foot needs straightening. There was also a girl who was a mill worker in a small town. She earned $\$ 14$ a week and her father, a shoe repairer, $\$ 15$. They supported the mother and a younger sister. Her hip badly injured in an accident, she left the hospital two months later. The accident happened in the fall; in the spring she could walk slowly, a short distance, with a cane. The operator of the car that injured her was sued and a judgment received for $\$ 3,600$. But he had no money. The lawyer attached his car which was sold for $\$ 360$. The lawyer took \$100 and gave the injured girl \$260. She had been to a specialist who charged her $\$ 25$ the first visit and after that nobly reduced his charge per visit to $\$$ ro, 
"because she was poor." When she found she could only receive $\$ 260$, she stopped going to the specialist, and her recovery was somewhere in the doubtful future.

Why is it that it is so hard for the imagination to encompass the distress of others unless it is conspicuous? People who visited Germany during the inflation period were sometimes surprised and disillusioned because they did not see human beings fainting from hunger in the streets. Many visitors refuse to recognize a slum unless it is accompanied by odors so trenchant as to drive them from the room. Not the least of the present consequences of automobile accidents is the inconspicuous pressure of unpaid debts, of a lowered standard of living, of lapsed insurance, of borrowing, of a future fraught, indefinitely, with insecurity. These simple stories reach fame only when someone is found dead of starvation or commits a picturesque robbery for bread. They exist, nonetheless, and, as they put strains upon the normal functioning of the family, they are also strains against a healthy social organization. Stated tersely, they merely hint at their detailed content-the daily approach to the grocer for further credit; the anxious scanning over the list of friends for one who may be asked for a loan; the search for assets to be made available to secure a finance company loan at $12 \%$ or more; the decision to face or avoid the unpaid landlord; the reluctant dropping of that small castle of security, the weekly insurance payment.

For instance, Emil Lindeman, a factory worker, was killed by an automobile as he was crossing an intersection. There were no witnesses to the accident. He left $\$ 250$ life insurance, a wife and a semi-invalid daughter. The father of the lad who drove the car said at the time, "Never mind about money. It's nothing to me. Don't worry." Meanwhile, ten months after the accident, nothing had been received and the local undertaker "was working on it." The daughter was working in a skate factory. They both lived on her earnings and the $\$ 25^{\circ}$ life insurance as long as it lasted. There were no debts to the grocer-"Rather do without"; but sometimes rent fell behind two or three months and sometimes there was no coal in the house; when there was, it was bought by the bag. Moreover, the factory's slack season was about to begin. This case is restated as the first of the series of case summaries which follow, so that the reader may more readily appreciate how much must be read between the lines of these terse statements.

Male head. Fatal. Went behind in rent. Daughter trying to support self and mother, though not well. No savings. Compensation pending.

Woman. Sole support of three. Out six weeks. Debts to grocer, butcher, commercial loans. No compensation.

Housewife. Continued illness after a year. Savings used up and lowered living standard. Compensation pending.

Male head. Long illness. Compensation covering expenses received after 6 months. Meanwhile family had to live and care for injured on $\$ 16$ weekly earnings of daughter.

Male head. Finger amputated. Now unemployed. Family of 7 live on wages of 16 year old boy. Compensation pending.

Child. 63 days in bed. 8 family members, no earners (father unemployed at time). Grocery bills owed. Borrowing from friends. No compensation. 
Housewife and earner. Three dependents. Owed for grocer, butcher, rent, coal and milk. Borrowed from son's employer. Still unable to work. No compensation.

One of 2 earners in family of 9. Permanent partial. Loans from relatives and Morris Plan. Case pending. Continued illness.

Child. Family borrowed from friends and relatives and commercial companies. No compensation.

Housewife and earner. Debts to grocer, loans from friends, relatives. No compensation.

Male head. Permanent partial. 5 dependents. Debts to grocer and butcher, friends and finance company. Still ill. Case pending.

Male head. Fatal. Wife and three dependents survive. \$2,000 life insurance received, nothing from uninsured driver. Family using up insurance.

Young girl, one of two earners (father out of work). In hospital 150 days, ill indefinitely. Family of six dependent on $\$ 8$ wage of other earner and profit from boarder. Compensation received 6 to $\mathrm{T}_{2}$ months after accident, less than expenses of first year of illness.

Male head. Serious injury, probably permanent. Three months in hospital. Compensation more than covering expenses up to time of settlement, received 8 months after accident. Meanwhile family owed grocer, landlord, coal dealer and drug store. Commercial loans at $12 \%$.

Casually employed. No family. Rent unpaid for six months. Relatives gave some food. Case pending.

Elderly mechanic. Alone. Made settlement of $\$ 50$ soon after accident. Still ill. Cared for by fellow worker.

One of 3 earners in family of 4. Family income $\$ 1,750$. Permanent partial, continued disability after 45 weeks. Commercial borrowing. Mother took in washing. Compensation, less than expenses, received 9 months after accident.

Elderly male head. Permanent disability. Unemployed since accident. Daughter borrowed money and dropped insurance to take care of him. Compensation, less than expenses, received 6 months to a year later.

Male head. Long illness. Used savings, owed grocer, butcher and commercial loan company. Unable to afford milk for sick child. No compensation.

High school lad. Fatal. Large family, one earner. Coroner paid medical expenses. Family borrowed from father's employer to pay for burial lot. Village took up collection for funeral expenses. No compensation.

Most of these cases are not spectacular. They were deliberately chosen to show a resulting impasse which, though sometimes acute in content, is not generally shocking to the outside view. There are, of course, cases where the effect on the home was more clearly shattering. Arden and his wife both worked, she being employed part time in a dormitory, earning $\$ 8.75$ a week. They were not young and their home was partly paid for. When he was killed there was no insurance. The operator of the car sold it to his brother and said he was unable to pay anything. The widow asked him to pay the funeral expense; he put her off, asking for more time. Taxes and sewer bill were unpaid, the house was given up to the mortgagee and the widow found a cheap room in a convent, living on her $\$ 8.75$ a week. There were other cases like that of Steve Carlson, where the injury of an earner drove the family to breaking up its household and to dependence on parents or brothers and sisters. There were some cases where, the family head killed and no compensation received, 
the children were distributed and the wife set out to earn her living, or the home was broken up and a child attempted to support the family. In one of these, a farmer was killed while driving his cows across the road. He left a widow, a son with St. Vitus dance and four other children, only one grown. There were no savings and no insurance. The operator of the car ran away but was captured. He was insured. Eleven months later, the case was still pending. Meanwhile the family had sold the stock to pay for grain, doctor's bills and funeral expenses, and had moved to town. The daughter found a poorly paid job in a factory, and the entire family lived on her wages for nearly a year. The charity organization offered to put mother and brother on the town poor farm but she refused. Finally, the brother also found some kind of work; but when last seen they were living from hand to mouth, owing rent and threatened with eviction, having borrowed $\$ 5$ from the grocer and \$ro from the undertaker.

We have said that a price is paid for physical progress as represented by the automobile and that some of that price is in human costs. Is it impossible for the social structure to be so modified as to reduce these human costs? 